\title{
Matteo Tarsi
}

\section{Samspil tökuorða og innlendra orða í samheitapörum í Priðju málfræðiritgerðinni}

\section{Inngangur}

Í greininni ${ }^{1}$ er fjallað um tökuorð og innlend orð sem birtast í samheitapörum í Priðju málfræðiritgerðinni (= PMR, frá u.p.b. 1250). Ritgerðin er ein af fjórum forníslenskum málfræðiritum (yfirlit hjá Magnúsi Snædal 1993) og er höfundur hennar Ólafur Pórðarson hvítaskáld (u.p.b. 1210-1259), bróðursonur Snorra Sturlusonar. Greinin er sýnishorn af stærri rannsókn á samlífi og samspili innlendra orða og tökuorða í íslenskum ritheimildum fram til siðaskipta árið 1550 (Tarsi væntanl.). ${ }^{2}$ Par er fengist við eftirfarandi meginrannsóknarspurningu: Hver var próun íslensks orðaforða í aðdraganda hreintungustefnunnar? Höfuðrannsóknin beinist m.ö.o. að íslenskum orðaforða og hefur

1 Ég vil pakka peim sem hafa veitt mér stuðning og hafa ekki síst verið mér ráðholl við ritun pessarar greinar: Ara Páli Kristinssyni, Helgu Hilmisdóttur (Stofnun Árna Magnússonar í íslenskum fræðum), Jóni Axel Harðarsyni og Margréti Jónsdóttur (Háskóli Íslands). Síðast en ekki síst pakka ég Mikael Males (Universitetet i Oslo) sem benti mér á meistararitgerð Victors Frans, sem ræddi við mig um efni ritgerðar sinnar og sendi mér hana strax eftir vörn svo að ég gæti nýtt mér hana í rannsókn minni. Rannsóknin fékk tveggja ára styrk frá Háskólasjóði Eimskipafélags Íslands á árunum 2018-2020.

2 Sambýli tökuorða og innlendra samheita peirra hefur áður verið rannsakað en pó einungis hvað nútímamálið varðar, sjá m.a. Guðrúnu Kvaran (2003:33-36), Ara Pál Kristinsson (2004:57-58), Ara Pál Kristinsson og Amanda Hilmarsson-Dunn (2015) og Tinnu Frímann Jökulsdóttur o.fl. (2019).

Orð og tunga 22 (2020), 69-96, https://doi.org/10.33112/ordogtunga.22.5

(C) höfundur CC BY-NC-SA 4.O. 
pann tilgang að varpa ljósi á samspil innlendra orða og tökuorða fyrir tíma hreintungustefnunnar, en fyrstu skýru heimildirnar um málræktaráhuga eru frá tíma siðaskipta (Kjartan G. Ottósson 1990:20).

Markmið pessarar greinar er að skoða samspil tökuorða og innlendra orða í PMR. Eftir að hafa fjallað í örfáum orðum um PMR, fyrirmyndir hennar og varðveislu (2) er fræðilegur bakgrunnur rannsóknarinnar kynntur og helstu hugtök skilgreind (3). Pessu næst er fjallað um greiningarpætti rannsóknarinnar (4) og svo samheitapörin greind (5). Par á eftir er umfjöllun um samheitapörin eftir pví hvernig pau birtast í textanum annars vegar og hvernig pau eru sett saman hins vegar, p.e. með tilliti til tegunda tökuorða og innlendra orða (6). Loks er fjallað um hvernig og til hvers höfundur PMR nýtir sér tökuorð og innlend samheiti peirra (7).

\section{Nokkur orð um Priðju málfræðiritgerðina, fyrirmyndir hennar og varðveislu}

Priðja málfræðiritgerðin skiptist í tvo hluta. Fyrri hlutinn nefnist Málfræðinnar grundvolllr og byggist hann á fyrstu tveim bindum Istitutiones grammaticæ eftir Priscianus (6. öld e.Kr.). Síðari hlutinn, Málskrúðsfræði, grundvallast á priðja bindi Ars maior eftir Donatus (4. öld e.Kr.) $)^{3}$ en víða sést að Ólafur hefur að mörgu leyti stuðst við skýringarrit, enda eru margar skýringar sem Ólafur tilfærir hvergi að finna í texta Donatusar. Skýringarritið sem Ólafur mun hafa farið eftir er rit sem hefur verið eignað Remigiusi frá Auxerre (u.p.b. 841-908) en mun samkvæmt tilgátu Males (2018) ekki vera eftir hann. Males (2018:322) kallar höfund pessa skýringarrits Pseudo-Remigius. Rannsóknir Frans (2019) á pessu riti (hdr. Biekorf 537) styðja tilgátu Males.

PMR er varðveitt í fjórum handritum en pó hvergi í heilu lagi. Handritin AM 242 fol., svokallað Codex Wormianus eða Wormsbók á íslensku (= W, frá um 1350), og AM 748 i b 4to (frá fyrsta fjórðungi 14. aldar) geyma hana að mestu leyti. Par að auki geymir síðara handritið elsta textann. Önnur brot af PMR eru varðveitt í AM 757 a og b 4to (fyrra brotið er frá um 1400 en hið síðara frá 15. öld).

Samkvæmt rannsókn Wills (2001:52-56) á skyldleika handrita PMR er honum pannig háttað að 748 og 757 a flokkast í sömu grein en Wormsbók í annarri grein í ættartrénu, en Björn M. Ólsen

3 Nánar um tengsl PMR við Priscianus og Donatus hjá Jóni Axel Harðarsyni (2016). 
(1884:xlviii-lxii) komst hins vegar að peirri niðurstöðu að Wormsbók og 748 væru sammæðra, en ekki 757 a; 757 b er hins vegar samkvæmt báðum fræðimönnunum beint afrit af W (Björn M. Ólsen 1884:liv, Wills 2001:52).

\section{Um tökuorð og innlend orð}

Í pessari rannsókn er gerður skýr munur á tökuorðum annars vegar og innlendum orðum hins vegar (sjá svipaðar rannsóknir í Betz 1959, Halldóri Halldórssyni 1964, Gusmani 1981 og nánar um greininguna í Tarsi væntanl.). Heitið tökuorð á hér við orð sem fengin eru úr annarri tungu og eru, að pví er virðist, virkur hluti af orðaforðanum, sama hvort pau eru aðlöguð eða ekki. ${ }^{4}$ I fræðilegri umræðu á Norðurlöndunum hefur síðan á tíunda áratug verið hefð fyrir pví að nota skandinavíska heitið importord (Jarvad 2007:10, sjá einnig m.a. Ástu Svavarsdóttur 2003 og Ara Pál Kristinsson 2004) sem samsvarar íslenska orðinu aðkomuorð. Undir peirri skilgreiningu bæri að kalla tökuorð einvörðungu pau orð sem fengin eru úr öðru máli en hafa aðlagast hljóð- og beygingarkerfi viðtökumálsins (Guðrún Kvaran 2005:343-344). Inn í pessa rannsókn eru engu að síður tekin erlend orð sem eru, ef tekið er mið af notkun í textanum, ekki virkur hluti af orðaforðanum, en pau skiptast samt á við innlend orð. Slík orð eru tvenns konar: styttingar (t.d. á nomina sacra eins og Dominus eða Christus) og augnablikstökuorð (e. nonce borrowing), p.e. orð lærðs uppruna sem ekki koma fyrir sem sjálfstæð orð í textanum heldur eru pau pöruð saman með samsvarandi innlendu samheiti, og eru pau undantekningarlaust erfðaorð (t.d. aurum - gull). Раð аð skilgreina pessi orð sem augnablikstökuorð fellur vel að efninu en erfitt er að segja með vissu eitthvað til um færni í erlendum málum stakra (oftast ópekktra) skrifara eða textahöfunda að fornu. Skilgreining mín byggist sem sagt á pví textasamhengi par sem pessi orð koma fyrir, og par með notkun peirra í textum, frekar en á aðlögunarpáttum, tíðni peirra í textum, tungumálakunnáttu höfundar eða viðhorfum hans til tökuorða.

Tökuorðin geta ýmist verið tekin inn í málið af nauðsyn, og pá kölluð nauðsynjatökuorð (e. necessity borrowing) eða vegna virðingar, p.e. virðingartökuorð (e. prestige borrowing) (sbr. Durkin

4 Sjá Ástu Svavarsdóttur og Veturliða Óskarsson (2009) um tökuorð og erlend áhrif í íslensku. 
2009:142-143). Nauðsynjatökuorð eru orð tekin inn í málið vegna skorts á orðum yfir ákveðið fyrirbæri eða ákveðinn hlut. Sem dæmi má nefna grunnorðin í kristni biskup, kirkja og prestur. Nauðsynin sem verið er að vísa til í heitinu nauðsynjatökuorð vísar til pess að verið sé að bæta úr skorti á heiti yfir ákveðna nýjung með tökuorði frekar en nýyrði.

Orð telst til virðingartökuorða ef pað gengur inn í orðaforðann eftir að innlent orð (eða tökuorð eða hvort tveggja) hefur skotið rótum í málinu. Sem dæmi má nefna margvísleg orð af miðlágpýskum uppruna sem áttu pegar samheiti i íslensku pegar pau birtust fyrst í rituðu máli, t.d. bítala, forbetra, forstanda, undirstanda (sjá nánar um pessi orð hjá Veturliða Óskarssyni 2003, og einkum Veturliða Óskarssyni 2015 um orð með forskeytinu bí-). Vert er svo að minna á að virðingin sem borin er fyrir ákveðnu erlendu máli í málsamfélagi getur leitt til pess að bæði nauðsynja- og virðingartökuorð verði tekin inn í heimatunguna. Pví hærri sem staða erlends tungumáls í málsamfélaginu er, pví meiri líkur eru á pví að bæði nauðsynja- og virðingartökuorð verði tekin inn í málið. Með öðrum orðum eykur há virðingarstaða líkurnar á að viðkomandi tunga sé valin sem veititunga.

Innlend orð eru heiti sem smíðuð eru af innlendum orðstofnum. Pau geta verið ferns konar: tökupýðingar, innlend nýgerð orð, erfðaorð og tökumerkingar. ${ }^{5}$ Tökupýðingar (e. structural calque) og innlend nýgerð orð (e. neoformation) eru lík að gerð, p.e. pau eru ýmist afleidd eða samsett orð, en munurinn er sá að tökupýðingar sýna greinileg erlend áhrif í formgerðinni, pær eru sem sagt pýðingar á erlendum heitum, jafnvel lið fyrir lið (t.d. meðalorpning < lat. interjectio). Innlend nýgerð orð ganga ekki út frá formgerð erlenda orðsins, sama hvort pað hafi gegnt einhverju hlutverki við myndun innlenda orðsins eða ekki (t.d. félagi, án fyrirmyndar; spámaðr, væntanlega með lat. propheta að merkingarlegri fyrirmynd). Erfðaorð (e. inherited word) og tökumerkingar (e. semantic calque) eru einnig lík að gerð. Erfðaorð eru kölluð hér pau orð sem hafa að öllum líkindum verið til síðan á

5 Orðaval petta er að mestu leyti sótt til Halldórs Halldórssonar í greininni Nýgervingum í fornmáli (1964:110-111), pó með breytingum. Par sem Halldór flokkar undir heitinu nýgerð orð öll pau orð sem eru nýsmíðuð í málinu, p.e. bæði tökupýðingar og nýyrði sem hafa ekki orðið til vegna erlendra áhrifa, er hér nauðsynlegt að halda pessum tveimur gerðum orða aðskildum. Par af leiðandi hef ég kosið að halda hefðbundnu nafni fyrri nýyrðategundar en kalla pá síðari innlend nýgerð orð, og er hér með lo. innlendur ekki einungis átt við hina ytri formgerð, heldur einnig um pað að orðasmíðin virðist ekki hafa orðið fyrir erlendum áhrifum, ef ekki einungis hugmyndalegum. 
frumgermönskum tíma. Merking peirra er hvorki í heild né að hluta fengin vegna erlendra áhrifa (t.d. feldr, hlutr). Undir skilgreininguna erfðaorð falla einnig afleidd orð sem eiga samstofna í öðrum germönskum málum, og pá í mismunandi greinum málaættarinnar, án pess að vera tökuorð. Pannig má segja að pau hafi orðið til á a.m.k. frumgermönskum tíma. Tökumerkingar eru í rauninni erfðaorð eða jafnvel afleidd orð sem hafa pó sætt merkingarútvíkkun vegna áhrifa erlends orðs (t.d. dróttinn < lat. Dominus, væntanlega um fe. dryhten).

\section{Um rannsóknina}

Samheitapörin sem rannsóknin beinist að eru skilgreind sem orðapör par sem annað orðið er tökuorð en hitt innlent. Einnig koma fyrir tilfelli par sem fleiri tökuorð samsvara einu innlendu orði eða öfugt í einu verki, t.d. samsvara tökuorðinu djofull prjú innlend orð í Íslensku hómilíubókinni, p.e. andskoti, fjándi og óvinr. Samt sem áđur er fyrirbærið ávallt skilgreint sem samheitapar.6

Samheitapörin, og par með orð sem pau samanstanda af, eru greind sem hér segir: handritafræðilega og textafræðilega, merkingarfræðilega og eftir tegund tökuorða annars vegar og innlendra orða hins vegar.

Handritafræðileg greining varðar dreifingu tökuorða og innlendra orða í textum par sem pau koma fyrir á sambærilegum stöðum í mismunandi handritum sama texta. Tilgangurinn er par af leiðandi að athuga hvort varðveisla tiltekins texta í handritum segi eitthvað til um notkun tökuorða annars vegar og innlendra orða hins vegar pegar pau mynda samheitapar í orðaforðanum. Textafræðilega greiningin segir hins vegar til um hvort og hvernig orðin skiptast á í ákveðnum texta, p.e. á mismunandi stöðum par sem oftast er samræmi milli handrita.

Merkingarfræðileg greining tekur til pess hvaða merkingarfræðilega sviði orðin tilheyra.

Flokkun orða er tvenns konar. Gerð er grein fyrir gerð tökuorða annars vegar og innlendra orða hins vegar. Tökuorðin eru flokkuð sem nauðsynja- eða virðingartökuorð. Innlend orð eru hins vegar greind í eftirfarandi flokka: tökupýðingar, innlend nýgerð orð, erfðaorð og tökumerkingar. Greining pessi varpar ljósi á pað hvernig samheiti af pessu tagi skiptast á í textum sem skrifaðir voru áður en hægt er að

6 Forníslensku orðin fylgja stafsetningu ONP. 
fara að tala um íslenska hreintungustefnu. Pví er í flestum tilvikum mögulegt að komast að pví hvort pað er tökuorðið eða innlenda orðið sem fyrr hafi komist í notkun miðað við varðveittar heimildir. Vitaskuld kunna orð að hafa verið í notkun fyrr eða síðar pótt við höfum ekki heimildir fyrir pví lengur. Auk alls pessa er einnig reynt að varpa ljósi á tökuferli sumra orða par sem lýsingin er ekki talin fullnægjandi í íslenskum orðsifjabókum ( $\mathrm{AeW}, \mathrm{IeW}, \mathrm{IOb})$.

Samheitapörin birtast á fjóra vegu í textunum: 1) á sambærilegum stöðum sama texta í mismunandi handritum 2) sem einföld víxl par sem pau koma fyrir á mismunandi stöðum í texta tiltekins verks, 3) sem skýringarinnskot og 4) sem samheitatvennur. Skýringarinnskot (e. explicative insertion) nefnast pau tilvik par sem innlent samheiti útskýrir erlent orð, en innlenda orðið er venjulega tilfært með orðalagi eins og pat er (á norrænu) eða sem vér kollum. Hitt kemur einnig fyrir, pó aðeins í örfáum tilvikum, p.e. að tökuorð er notað sem skýring á innlendri smíð eins og t.d. í Elucidarius (AM 544 4to, Scherabon Firchow og Grimstad 1989:128 ${ }^{10}$ ): "Jórsalaborg pat er Hierusalem". Samheitatvennur (e. synonymic dittology) eru tilvik par sem erlenda og innlenda orðið eru pöruð saman með samtengingunni og eða eða í skýringarhlutverki, p.e. hún pýðir 'pað er (að segja)', 'með öðrum orðum'.

Í málfræðiritgerðunum fjórum er ekki um auðugan garð að gresja hvað varðar pann hluta orðaforðans sem hér er til rannsóknar. Samheitapör í pessum fjórum verkum eru fá að meðaltali, og eru t.d. engin samheitapör í Fyrstu málfræðiritgerðinni (skr. 1130-1140). Í Annarri málfræðiritgerðinni (skr. 1270-1300) er á hinn bóginn einungis eitt samheitapar að finna, p.e. músíka - songr, par sem í Fjórðu málfræðiritgerðinni (skr. 1320-1340) birtast tvö samheitapör (præpositio - fyrirsetning; vers - vísuorð). PMR sker sig úr hópnum, en í henni er að finna 20 samheitapör.

Dreifing samheitapara í mismunandi handritum segir ekki mikið til um hvort stemma, sem fyrr var vikið að, er rétt. Vert er pó að geta pess að W og 748 ber saman í öllum tilfellum nema hvað varðar samheitapörin (cœlestis) armonia - (himnesk) hljóðagrein og punkta - stinga. Í fyrra tilfellinu ber 748 og 757 a saman á móti W, par sem orðunum himnesk hljóðagrein er sleppt, en í hinu síðara varðveita 748 og W mismunandi lesbrigði hvað orðið stinga varðar (sbr. Töflu 2), en er ekki að finna á sambærilegum stað í 757 a. Petta síðara tilfelli geymir pó ekki pýðingarmikinn orðalagsmun en 748 hefur vafalaust rétta lesháttinn (pá er hann er stunginn) par sem W sýnir mistök sem stafa sennilegast af mislestri (er pá stundum), en textabúturinn rétt á undan 
segir "ok er íss stundum settr fyrir $\mathrm{e}^{\prime \prime}$.

Í pví sem á eftir fer verða samheitapör í PMR greind. Í niðurlagi greinarinnar er svo sagt frá pví hver tengsl merkingarsviðs samheitapara og birtingartegunda peirra eru, og svo pví hvernig sambandi tegunda tökuorða og smíð innlendra orða er háttað.

\section{Samheitapör í Priðju málfræðiritgerðinni}

Samheitapör í PMR mynda bæði nafnorð og sagnorð. Nafnorðin eru greind eftir merkingarsviði í sex flokka. Sagnirnar mynda tvo flokka, p.e. bendisagnir og verknaðarsagnir. Í Töflu 1 eru samheitapör flokkuð eftir merkingarsviði.

\begin{tabular}{|l|l|}
\hline Merkingarsvið & Samheitapör \\
\hline MÁLFRÆĐI & $\begin{array}{l}\text { diphthongus - tvíhljóðr } \\
\text { fígúra - mynd/vǫtr } \\
\text { nóti - merking }\end{array}$ \\
\hline ALMENNUR LÆRDÓMUR & philosophus - spekingr \\
\hline NÁTTÚRA & $\begin{array}{l}\text { (cœlestis) armonia - (himnesk) hljóðagrein } \\
\text { elementum - hǫfuðskepna }\end{array}$ \\
\hline EIGINLEIKAR & sen - merking \\
\hline MAGN & partr - hlutr \\
\hline MÁLSKRÚĐS- OG SKÁLD- & $\begin{array}{l}\text { anadiplosis - drǫgur } \\
\text { apocope - orðkolfr } \\
\text { SKAPARFRÆĐI } \\
\text { enismus - brugðning/spell, slita/sundrskorning }- \text { gáta } \\
\text { lexis - rǿða } \\
\text { paronomasia - aðalhending } \\
\text { periphrasis - umkringingarmál } \\
\text { rhetorica - málssnilldarlist } \\
\text { schema - skrúð } \\
\text { vers - vísuorð }\end{array}$ \\
\hline nótera - merkja \\
\hline BENDISAGNIR & punkta - stinga \\
\hline VERKNAĐARSAGNIR
\end{tabular}

Tafla 1: Merkingarsvið samheitapara í PMR. 
Samheitapörin í PMR eru tilgreind í Töflu 2. Blaðsíðu- og línunúmer, sem eru innan sviga við hliðina á viðkomandi orði samsvara pví sem finna má í útgáfu Björns M. Ólsens (1884). Í öðrum dálki er svo gerð grein fyrir birtingartegundum orðapara og heimildum Ólafs, Donatus og Pseudo-Remigius, pegar pær eru fyrir hendi. Athugasemdir birtast svo í priðja dálki.

\begin{tabular}{|c|c|c|}
\hline $\begin{array}{l}\text { Samheitapör og } \\
\text { staðsetningar í } \\
\text { handriti }\end{array}$ & $\begin{array}{l}\text { Birtingarmynd í } \\
\text { handritum }\end{array}$ & $\begin{array}{l}\text { Athugasemdir um } \\
\text { frumheimildir }\end{array}$ \\
\hline $\begin{array}{l}\text { anadiplosis }\left(94^{49}\right)- \\
\text { drogur }\left(94^{55}\right)\end{array}$ & $\begin{array}{l}\text { Skýringarinnskot í } \\
\text { W og } 748 .\end{array}$ & $\begin{array}{l}\text { Donatus notar anadiplosis. } \\
\text { Pseudo-Remigius gerir grein } \\
\text { fyrir gríska orðinu og pýðir } \\
\text { pað á latínu. }\end{array}$ \\
\hline $\begin{array}{l}\text { apocope }\left(88^{39}\right)- \\
\text { orðkolfr }\left(88^{43}\right)\end{array}$ & $\begin{array}{l}\text { Skýringarinnskot í } \\
\text { W og } 748 .\end{array}$ & $\begin{array}{l}\text { Donatus notar apocope. } \\
\text { Pseudo-Remigius notar } \\
\text { latneskt orð til að útskýra } \\
\text { merkingu gríska orðsins. } \\
\text { OIcel. orðkolfr er einnig } \\
\text { notað pegar talað er um } \\
\text { fyrirbæri sem Donatus nefnir } \\
\text { soløcismus per casus, p.e. } \\
\text { málslöst sem er fólginn í pví } \\
\text { að nota rangt fall (sbr. Björn } \\
\left.\text { M. Ólsen } 1884: 77^{65-69}\right) \text {. }\end{array}$ \\
\hline $\begin{array}{l}\text { (colestis) armonia } \\
\left(34^{24-25}\right)-(\text { himnesk) } \\
\text { hljóðagrein }\left(34^{24-25}\right)\end{array}$ & $\begin{array}{l}\text { Samheitatvenna í } \\
748 \text { og } 757 \text { a. Aftur } \\
\text { á móti er orðunum } \\
\text { himnesk hljóðagrein } \\
\text { sleppt í W og } 757 \text { b. }\end{array}$ & \\
\hline
\end{tabular}




\begin{tabular}{|c|c|c|}
\hline $\begin{array}{l}\text { Samheitapör og } \\
\text { staðsetningar í } \\
\text { handriti }\end{array}$ & $\begin{array}{l}\text { Birtingarmynd í } \\
\text { handritum }\end{array}$ & $\begin{array}{l}\text { Athugasemdir um } \\
\text { frumheimildir }\end{array}$ \\
\hline $\begin{array}{l}\text { cismus }\left(69^{131}, 73^{11}\right) \\
\text { - brugðning/spell, } \\
\text { slita/sundrskorning } \\
\left(69^{131}, 73^{11}\right)\end{array}$ & $\begin{array}{l}\text { Orðin mynda } \\
\text { skýringarinnskot í } \\
\text { PMR sem hér segir: } \\
\text { cismus - brugðning/ } \\
\text { spell í öllum } \\
\text { handritum sem } \\
\text { varðveita textann } \\
\text { par sem orðmyndin } \\
\text { kemur fyrir. cismus - } \\
\text { slita/sundrskorning er } \\
\text { einungis í W og } 748 .\end{array}$ & 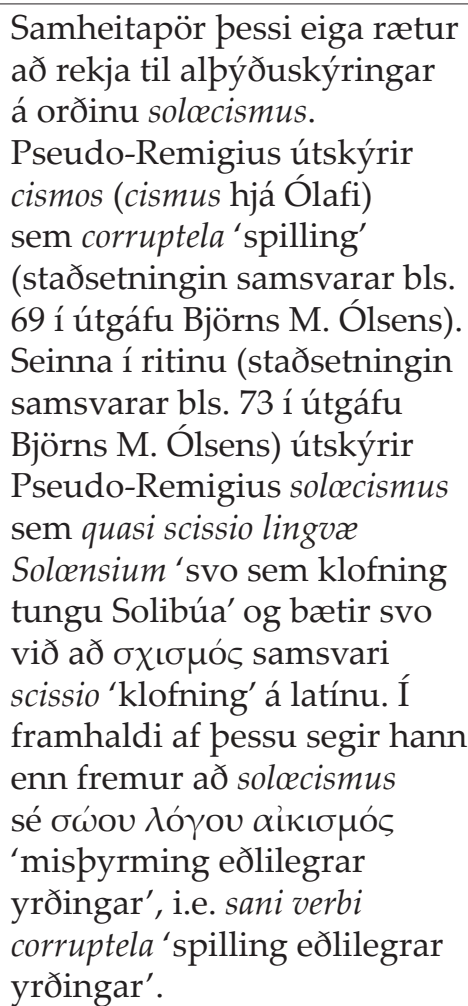 \\
\hline $\begin{array}{l}\text { diphthongus }\left(47^{29,30,}\right. \\
\text { 31) - tvíhljódr }\left(47^{29}\right)\end{array}$ & $\begin{array}{l}\text { Skýringarinnskot } \\
\text { í öllum handritum } \\
\text { sem varðveita } \\
\text { staðsetninguna. }\end{array}$ & \\
\hline $\begin{array}{l}\text { elementum }\left(38^{25}\right)- \\
\text { hofuðskepna }\left(38^{25}\right)\end{array}$ & $\begin{array}{l}\text { Skýringarinnskot } \\
\text { í öllum handritum } \\
\text { sem varðveita } \\
\text { staðsetninguna. }\end{array}$ & \\
\hline $\begin{array}{l}\text { enigma }\left(114^{252}\right)- \\
\text { gáta }\left(114^{257}\right)\end{array}$ & $\begin{array}{l}\text { Skýringarinnskot í } \\
\text { W og } 748 .\end{array}$ & $\begin{array}{l}\text { Donatus notar orðið enigma. } \\
\text { Pseudo-Remigius er ekki með } \\
\text { sambærilega staðsetningu en } \\
\text { hann segir annars staðar í riti } \\
\text { sínu að enigma pýði obscuritas } \\
\text { 'myrkur, torræðni, eitthvað } \\
\text { sem er óskiljanlegt'. }\end{array}$ \\
\hline
\end{tabular}




\begin{tabular}{|c|c|c|}
\hline $\begin{array}{l}\text { Samheitapör og } \\
\text { staðsetningar í } \\
\text { handriti }\end{array}$ & $\begin{array}{l}\text { Birtingarmynd í } \\
\text { handritum }\end{array}$ & $\begin{array}{l}\text { Athugasemdir um } \\
\text { frumheimildir }\end{array}$ \\
\hline $\begin{array}{l}\text { figúra }\left(40^{1}, 45^{1},\right. \\
\left.82^{69}, 84^{113}\right)- \text { mynd/ } \\
\text { voxtr }\left(45^{1}\right)\end{array}$ & $\begin{array}{l}\text { Skýringarinnskot } \\
\text { í öllum handritum } \\
\text { sem varðveita } \\
\text { staðsetningarnar. }\end{array}$ & $\begin{array}{l}\text { Auk merkingar 'form stafs' } \\
\text { (bls. } 40^{1}, 45^{1} \text { ), gat fígúra } \\
\text { merkt einnig 'retórísk } \\
\text { fígúra, stílbragð' (bls. } 82^{69}, \\
84^{113} \text { ). Priscianus, Donatus } \\
\text { og einnig Pseudo-Remigius } \\
\text { nota einungis orðið figura. } \\
\text { Físl. voxtr er einnig að finna } \\
\text { í Fyrstu málfræðiritgerðinni } \\
\text { par sem orðið pýðir 'form } \\
\text { stafs sem samansetning sinna } \\
\text { hluta' en í merkingunni 'form } \\
\text { stafs (sem heild)' er notað } \\
\text { orðið líkneski (sbr. Hrein } \\
\text { Benediktsson 1972:64-66). }\end{array}$ \\
\hline $\begin{array}{l}\text { lexis }\left(91^{6}\right)-r \not ́ \delta a \\
\left(91^{6}\right)\end{array}$ & $\begin{array}{l}\text { Skýringarinnskot í } \\
\text { W og } 748 .\end{array}$ & $\begin{array}{l}\text { Pseudo-Remigius tilfærir lat- } \\
\text { neska pýðingu á gríska orð- } \\
\text { inu, p.e. dictio ‘yrðing, segð’. }\end{array}$ \\
\hline $\begin{array}{l}\text { nótera }\left(55^{10,14}\right)- \\
\text { merkja }\left(55^{7,10}\right)\end{array}$ & $\begin{array}{l}\text { Orð pessi skiptast } \\
\text { á í texta PMR (bls. } \\
\left.55^{10} \text { og } 55^{7}\right) \text { í W, } 757 \text { b } \\
\text { og } 748 . \text { Par að auki } \\
\text { eru orðin tvö notuð } \\
\text { á sambærilegum } \\
\text { stað (bls. } 55^{10} \text { ) } \\
\text { í mismunandi } \\
\text { handritum par sem } \\
757 \text { a hefur merkja } \\
\text { en hin handritin } \\
\text { sem varðveita orð- } \\
\text { myndina hafa nótera. }\end{array}$ & \\
\hline $\begin{array}{l}\text { nóti }\left(54^{7}\right)-\text { merking } \\
\left(54^{7}\right)\end{array}$ & $\begin{array}{l}\text { Samheitatvenna. } \\
\text { Orðunum fylgir } \\
\text { eignarfallsandlagið } \\
\text { áblásningar. }\end{array}$ & $\begin{array}{l}\text { Priscianus notar nota } \\
\text { aspirationis 'merki } \\
\text { áblásningar'. }\end{array}$ \\
\hline $\begin{array}{l}\text { paronomasia }\left(95^{73}\right)- \\
\text { aðalhending }\left(96^{77}\right)\end{array}$ & $\begin{array}{l}\text { Skýringarinnskot í } \\
\text { W og } 748 .\end{array}$ & $\begin{array}{l}\text { Donatus notar orðið } \\
\text { paronomasia. Pseudo- } \\
\text { Remigius pýðir gríska orðið } \\
\text { lið fyrir lið á latínu: } \pi \alpha \varrho \alpha ́ \\
\text { 'de', óvo } \alpha \alpha \sigma \alpha^{\prime} \alpha \text { 'nominatio'. }\end{array}$ \\
\hline
\end{tabular}




\begin{tabular}{|c|c|c|}
\hline $\begin{array}{l}\text { Samheitapör og } \\
\text { staðsetningar í } \\
\text { handriti }\end{array}$ & $\begin{array}{l}\text { Birtingarmynd í } \\
\text { handritum }\end{array}$ & $\begin{array}{l}\text { Athugasemdir um } \\
\text { frumheimildir }\end{array}$ \\
\hline $\begin{array}{l}\text { partr }\left(45^{8}, 56^{5}\right)- \\
\text { hlutr }\left(56^{1}, 56^{5}\right)\end{array}$ & $\begin{array}{l}\text { Orð pessi skiptast } \\
\text { á í W, } 757 \text { b og } 748 . \\
\text { Einnig skiptast pau } \\
\text { á í mismunandi } \\
\text { handritum (bls. } \\
56^{5} \text { ) par sem } 757 \text { a } \\
\text { hefur hlutr en hin } \\
\text { handritin hafa partr. }\end{array}$ & $\begin{array}{l}\text { Priscianus notar orðið pars } \\
\text { 'hluti'. }\end{array}$ \\
\hline $\begin{array}{l}\text { periphrasis }\left(109^{177}\right) \\
\text { - umkringingarmál } \\
\left(109^{177-178}\right)\end{array}$ & $\begin{array}{l}\text { Skýringarinnskot í } \\
\text { W og } 748 .\end{array}$ & 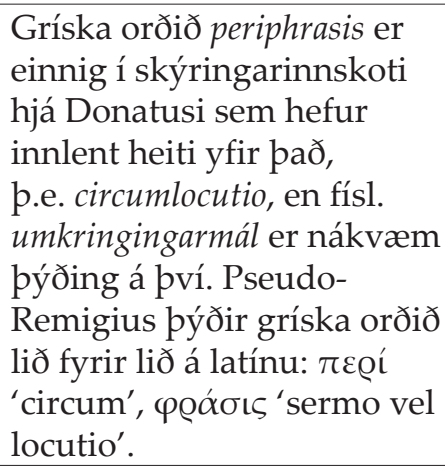 \\
\hline $\begin{array}{l}\text { philosophus }\left(34^{21}\right)- \\
\text { spekingr }\left(60^{14-15}\right)\end{array}$ & $\begin{array}{l}\text { Orð í pessu sam- } \\
\text { heitapari skiptast á } \\
\text { í texta PMR að } 757 \text { a } \\
\text { undanskildu, en } \\
\text { íslenska orðið er ekki } \\
\text { varðveitt par. }\end{array}$ & \\
\hline $\begin{array}{l}\text { punkta }\left(42^{28}\right)- \\
\text { stinga }\left(42^{22}\right)\end{array}$ & $\begin{array}{l}\text { Orð pessi skiptast á í } \\
\text { texta } 748 .\end{array}$ & \\
\hline $\begin{array}{l}\text { rhetorica }\left(96^{86}\right)- \\
\text { málssnilldarlist } \\
\left(96^{85}\right)\end{array}$ & $\begin{array}{l}\text { Skýringarinnskot í } \\
\text { W og } 748 .\end{array}$ & \\
\hline $\begin{array}{l}\text { schema }\left(91^{5}\right)-\text { skrúð } \\
\left(91^{5}\right)\end{array}$ & $\begin{array}{l}\text { Skýringarinnskot í } \\
\text { W og } 748 .\end{array}$ & $\begin{array}{l}\text { Pseudo-Remigius tilfærir } \\
\text { latneska pýðingu á gríska } \\
\text { orðinu (í ft. í textanum, } \\
\text { schemata), p.e. figuræ } \\
\text { vel habitus 'form eða } \\
\text { birtingarmyndir'. }\end{array}$ \\
\hline
\end{tabular}




\begin{tabular}{|l|l|l|}
\hline $\begin{array}{l}\text { Samheitapör og } \\
\text { staðsetningar í } \\
\text { handriti }\end{array}$ & $\begin{array}{l}\text { Birtingarmynd í } \\
\text { handritum }\end{array}$ & $\begin{array}{l}\text { Athugasemdir um } \\
\text { frumheimildir }\end{array}$ \\
\hline $\begin{array}{l}\text { sen }\left(67^{100}, 81^{62},\right. \\
\left.114^{252}\right)- \text { merking } \\
\left(36^{43}\right)\end{array}$ & $\begin{array}{l}\text { Orð pessi skiptast á í } \\
\text { texta PMR. } \\
\text { Físl. sen er notað til } \\
\text { útskýringar á tveim } \\
\text { stílfígúrum, p.e. } \\
\text { macrologia (langt sen) } \\
\text { og enigma (myrkt } \\
\text { sen). }\end{array}$ & $\begin{array}{l}\text { Donatus útskýrir enigma } \\
\text { sem obscura sententia } \\
\text { 'óskýr málsgrein'. Pseudo- } \\
\text { Remigius tilfærir eftirfarandi } \\
\text { skýringarsetningu eftir } \\
\text { macrologia: id est longa dictio } \\
\text { vel sententia 'pað er löng } \\
\text { yrðing eða málsgrein'. }\end{array}$ \\
\hline $\begin{array}{l}\text { vers }\left(52^{31}(\div 757 \text { a), }\right. \\
\left.94^{50,51}, 95^{62}\right)-\end{array}$ & $\begin{array}{l}\text { Orð pessi skiptast á í } \\
\text { texta PMR. }\end{array}$ & $\begin{array}{l}\text { Donatus notar orðið versus } \\
\text { 'vers'. }\end{array}$ \\
\hline vísorð $\left(92^{16}\right)$
\end{tabular}

Tafla 2: Samheitapör í PMR.

Hér á eftir eru tökuorðin og innlendu orðin flokkuð auk pess sem sagt er frá uppruna tökuorða og gerð innlendrar smíðar. Reynt er að varpa ljósi á pað hvort tökuorð eða innlend orð hafi fyrst verið notuð í málinu. Innan sviga á eftir viðkomandi orði eru upplýsingar um elsta dæmi í ritmáli, aldur verks og handrits, par sem dæmið er varðveitt. Skammstafanir á heiti verkanna eru eftir Ordbog over det norrøne prosa$\operatorname{sprog}(=\mathrm{ONP})$ fyrir verk í óbundnu máli, eftir Lexicon Poeticum (= LP) fyrir verk í bundnu máli. Að lokum er útgáfu heimilda getið ef um verk í óbundnu máli er að ræða. Aldur verkanna er sóttur til helstu útgáfna peirra. Aldur handritanna er eftir ONP.

anadiplosis -drogur: Lat. anadiplosis (Gramm ${ }^{3} 748$ u.p.b. $1250>$ AM 748 i b 4to 1300-1325, Björn M. Ólsen 1884) er fengið úr fgr. $\alpha v \alpha \delta i ́ \pi \lambda \omega \sigma \iota \varsigma$ 'endurtekning', sem er leitt af so. ḋv $\alpha \delta ı \pi \lambda o ́ \omega$ 'tvöfalda, endurtaka'.

Físl. drogur (SnE u.p.b. 1220 > GKS 2367 4to 1300-1350, Finnur Jónsson 1931) er heiti stílfígúru nokkurrar par sem síðasta orð í vísuorði er endurtekið í byrjun næsta vísuorðs. Orðið er íslenskt íðorð og er fleirtalan af no. draga. Orðið er innlent nýgert orð, en skáldskaparfræðilega merkingu pess er einungis að finna í íslensku.

Innlenda orðið er partur af íðorðaforða kveðskaparins en erlenda heitið virðist fengið beint úr ritgerð Donatusar. Par af leiðandi er líklegt að innlenda orðið hafi verið notað í íslensku á undan pví erlenda. Lat. anadiplosis er eitt peirra fræðiheita sem Ólafur fær beint úr fyrirmyndinni og ber pví að túlka sem nauðsynjatökuorð, pó að innlent heiti samsvari erlenda orðinu. Pví til frekari stuðnings má 
geta pess að ekki er innlent samheiti á öllum latneskum stílfígúrum sem Ólafur fjallar um. Par að auki er innlent heiti einu sinni notað yfir tvö mismunandi fyrirbæri (sjá neðar, u. apocope - orðkolfr), en í annað skipti er innlent heiti notað sem samheiti yfir latneskt heiti en heitin tvö tákna í rauninni mismunandi fyrirbæri sem lítið eiga sameiginlegt (sjá neðar, u. paronamasia-aðalhending).

apocope - orðkolfr : Lat. apocope (Gramm 3748 u.p.b. 1250 > AM 748 i b 4to 1300-1325, Björn M. Ólsen 1884) er tökuorð úr fgr. ঝ̇токоти́ 'brottfall hljóðs, hljóða eða atkvæðis í bakstöðu, apókópa', sem leitt er af so. $\alpha \pi$ «ó́ $\pi \tau \omega$ 'skera, klippa, höggva af'.

Físl. orðkolfr 'brottfall hljóðs, hljóða eða atkvæðis í bakstöðu, apókópa' (Gramm 3748 u.p.b. 1250 > AM 748 i b 4to 1300-1325, Björn M. Ólsen 1884) er samsett af orð og kolfr (réttara: kólfr) 'klukkukólfur, dingull, ör, kastspjót, kastvopn, járnbolti'. Ekki er augljóst hvernig ber að skilja samband orðanna orð og kolfr í samsetningunni. Upprunaleg merking rótarinnar (forfrg. ${ }^{*} g e l b^{h}-/ g l e b^{h_{-}}$) virðist hafa verið eitthvað á borð við 'pressa saman, móta kúlu úr e-u' (sbr. IdgeW, u. gel-1). Má pví velta fyrir sér hvort polmyndarmerking hafi verið í orðinu kolfr, svo að orðið gæti verið notað til að tákna styttri gerð einhvers orðs. Pess ber svo að geta að samsvarandi orð í dönsku og nýnorsku (kolv) pýða 'kylfa', sbr. einnig náskylda íslenska orðið kylfa. Par af leiðandi má færa rök fyrir pví að orðið kolfr, pó að pað sé ekki varðveitt eitt og sér, hafði sömu merkingu og d./nýn. kolv. Grunnmerking orðsins orðkolfr væri pá 'orðkylfa'. I yfirfærðri merkingu 'kylft orð' var orðið notað til að tákna lat. apocope (sbr. orðatiltækið að kylfa til orðanna 'stama', so. kylfa er einungis að finna í pessu orðatiltæki). Físl. orðkolfr notar Ólafur einnig pegar talað er um ranga fallnotkun (soloecismus per casus, sbr. Björn M. Ólsen 1884:7765-69). Á báðum stöðum notar Ólafur sömu vísuorð (pví hefik heitit mey mætri / mest nema hamlan bresti) til að gera grein fyrir tveim mismunandi fyrirbærum. Pegar talað er um apókópu, túlkar Ólafur orðmyndina mey sem págufallshliðarmynd af mær (p.e. mеуju > mey; nf. mær, pf. mey, pgf. mey, ef. meyjar o.s.frv.). Aftur á móti túlkar Ólafur í síðara tilvikinu sama orðið sem polfallsmynd en ekki págufallsmynd (p.e. nf. mær, pf. mey, pgf. meyju, ef. meyjar o.s.frv.), p.e. hann á við að polfallsmynd sé notuð í stað págufalls.

Tökuorðið er væntanlega til komið af nauðsyn (anadiplosis - drogur), en innlenda orðið orðkolfr er innlent nýgert orð sem finnst einungis í PMR, skv. ONP. Pað er pví óvíst hvort Ólafur sjálfur hafi smíðað orðið orðkolfr. 
(coelestis) armonia - (himnesk) hljóðagrein: Lat. harmonia 'samsvörun, samræmi, samhljómur' (Gramm 3448 u.p.b. 1250 > AM 748 i b 4to 1300-1325, Björn M. Ólsen 1884) er tökuorð af grískum uppruna í latínu. Fgr. ¿@@uoví $\alpha$ 'samræmi, samkomulag' er leitt af lýsingarorði * $\varrho \mu \omega \nu$ sem er ekki varðveitt sem sjálfstætt orð en spor pess má pó

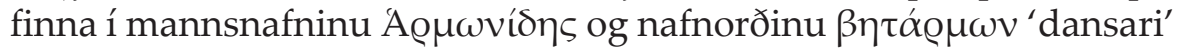
(sbr. GeW, u. $\alpha \varrho \mu$ oví $\alpha$ ).

Físl. hljóðagrein 'samsvörun, samræmi, samhljómur' (Gramm ${ }^{3} 748$ u.p.b. 1250 > AM 748 i b 4to 1300-1325, Björn M. Ólsen 1884) samsvarar hljóðsgrein og hljóðgrein (sbr. ONP, u.o.). Í PMR er orðið notað í tveim merkingum: annars vegar pegar talað er um samhljóm reikistjarnanna (p.e. colestis armonia) og hins vegar pegar Ólafur heimfærir gríska áherslukerfið upp á íslensku. Í síðara tilvikinu samsvarar físl. hljóðagrein lat. tenor.

Innlenda heitið gæti hafa verið smíðað eftir lat. soni differentia. Latneska heitið hlýtur að hafa verið pekkt. Vitneskja um latneska heitið er möguleg forsenda pess að mynda hið íslenska orð. Samt sem áður virðist latneska heitið ekki notað í íslensku annars staðar en í PMR. Ef til vill má stinga upp á að latneska orðið hafi verið fengið í PMR sem virðingartökuorð (sbr. einnig neðar u. fígúra - mynd/voxtr).

cismus - brugðning/spell, slita/sundrskorning: Orðið *cismus (Gramm ${ }^{3} 748$ u.p.b. 1250 > AM 748 i b 4to 1300-1325, Björn M. Ólsen 1884) er ekki til í latínu en í PMR er pað partur af alpýðuskýringu á gríska orðinu

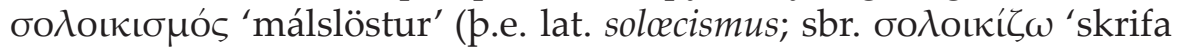

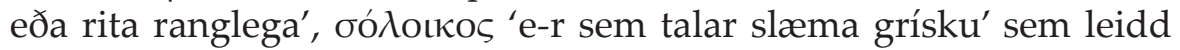
eru af nafni borgarinnar Soli ( $\Sigma o ́ \lambda o \iota)$. Annað dæmi um pessa afleiðslu

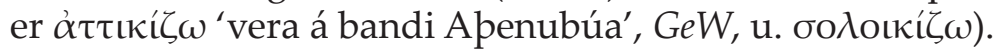

Físl. brugðning (Gramm 3748 u.p.b. 1250 > AM 748 i b 4to 1300-1325, Björn M. Olsen 1884) er leitt af so. bregða (innlent nýgert orð). Físl. spell (HSt Rst 12 ${ }^{\text {th }}$ c. > AM 61 fol. 1350-1375, LP) er erfðaorð (sbr. OE spild 'eyðing, tortíming' og spildan 'eyða', OSax. spildian 'drepa', OHG spilden 'eyða', sjá einnig IdgeW, u. (s)p(h)el-1), Físl. slita $\left(\mathrm{Gramm}^{3} 748\right.$ u.p.b. 1250 > AM 748 i b 4to 1300-1325, Björn M. Ólsen 1884) er leitt af so. slíta en físl. sundrskorning (Gramm ${ }^{3} 748$ u.p.b. $1250>$ AM 748 i b 4to 1300-1325, Björn M. Ólsen 1884) er leitt af so. skera sundr, og eru bæði orðin innlend nýgerð orð.

Lat. *cismus er augljóslega augnablikstökuorð, en pað er hluti af skýringu Ólafs á orðinu solæcismus. Orðið á uppruna sinn að rekja til skýringarrits eftir Pseudo-Remigius og pá til frg. $\sigma \chi\llcorner\sigma \mu o ́ \varsigma$ 'klofning', 
sem hann nefnir, frekar en frg. $\sigma \chi i ́ \sigma \mu \alpha$ 'rauf, brestur', eins og Finnur Jónsson hefur getið til í útgáfu sinni á verkinu (Finnur Jónsson 1927: 50, nmgr. á 1. 1).

diphthongus - tvíhljóðr : Lat. diphthongus 'tvíhljóð' (Gramm³748 u.p.b. 1250 > AM 748 i b 4to 1300-1325, Björn M. Ólsen 1884) er tökuorð úr

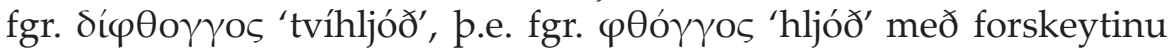
$\delta \iota^{-}$'tví-' (sjá nánar Lex.Lat.GT, u. diphthongus).

Físl. tvíhljódr (Gramm3748 u.p.b. 1250 > AM 748 i b 4to 1300-1325, Björn M. Ólsen 1884) er tökupýðing á lat. diphthongus. Orðið er einvörðungu að finna í PMR skv. ONP. Auk pess er orðið notað aðeins einu sinni í ritgerðinni par sem Ólafur notar annars tökuorðið.

Af notkun orðanna tveggja í PMR virðist pað sennilegt að tökuorðið sé tilkomið af nauðsyn og að innlenda orðið hafi pví verið smíðað eftir að tökuorðið var komið í notkun. Að auki má stinga upp á að Ólafur hafi staðið að smíði íslenska orðsins, en pað er notað sem skýring á latneska heitinu. Í PMR er orðið límingarstafr einnig notað í merkingunni 'tvíhljóð’ en par er rætt um tvíhljóð í rúnum (Björn M. Ólsen 1884: $47^{33}-48^{1}$, sbr. enn fremur Raschellà 2004:22-25).

elementum - høfuðskepna : Lat. elementum 'höfuðskepna, hljóð, staf-

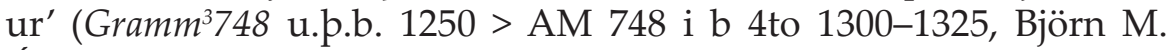
Ólsen 1884) er af óljósum uppruna (sjá LeW, u.o. og einnig Lex.Lat. GT, u. elementum og littera). Раð аð kalla stafi elementa er í latínu eftir

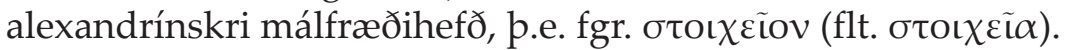

Físl. hofuðskepna (Eluc674(1989) seinni hluta 12. aldar >AM 674 a 4to 1150-1200, Scherabon Firchow og Grimstad 1989) er samsett af hofuठ og skepna. Orðið hefur verið smíðað sem samheiti við einungis hluta af merkingum orðsins elementum, p.e. hina trúarlegu og náttúrutengdu merkingu. Erlenda orðið virðist vera augnablikstökuorð í PMR.

enigma - gáta : Lat. ænigma 'gáta' (Gramm 3448 u.p.b. $1250>$ AM 748 i b 4to 1300-1325, Björn M. Ólsen 1884) er tökuorð úr fgr. $\alpha$ ǐv $\gamma \mu \alpha$ 's.m.',

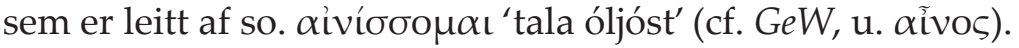

Físl. gáta (Gestumbl Heiðr 13 ${ }^{\text {th }}$ c. > AM 544 4to 1302-1310, LP) er leitt af so. geta. Orðið ber að túlka sem erfðaorð, en orð samstofna pví eru einungis í norðurgermönsku: fær. gáta, nýn. gåte, sæ. gåta, d. gåde. Samt sem áður er indóevrópska rót so. geta, i.e. ${ }^{*} g^{h} e d-$, víða að finna í indóevrópsku málafjölskyldunni, ekki síst í germönsku (t.d. got. bigitan 'finna', fhp. ergezzen 'gleyma', $L I V^{2}$, u. $g^{h} e d-{ }^{1}$ ).

Innlenda orðið er bein pýðing á erlenda heitinu. Latneska orðið 
ber að túlka sem nauðsynjatökuorð eins og önnur heiti yfir stílfígúrur í PMR.

fígúra - mynd/voxtr : Físl. fígúra (Algor u.p.b. 1250 > AM 544 4to 13021310, Eiríkur Jónsson og Finnur Jónsson 1892-1896) er tökuorð úr lat. figura 'mynd, lögun, skapnaður, tölustafur' (IeW, AeW, ÍOb, u.o.; sjá enn fremur Lex.Lat.GT, u.o.).

Físl. mynd (HómÍsl(1993) u.p.b. 1200 > Stock. perg. 15 4to u.p.b. 1200, de Leeuw van Weenen 1993) er erfðaorð. Samstofna orð í germönskum málum eru t.d. got. gamunds og fe. gemynd 'minni'. Físl. voxtr (Eluc674(1989) seinni hluta 12. aldar > AM 674 a 4to 1150-1200, Scherabon Firchow og Grimstad 1989) er leitt af so. vaxa.

Innlendu orðin hafa að öllum líkindum verið fyrst notuð í almennri merkingu. Samt sem áður var málfræðileg merking pessara orða fengin úr latínu og pví var vitneskja um latneska heitið nauðsynleg forsenda pess að nota innlendu orðin í málfræðilegum skilningi. Tökuorðið ber pví að túlka sem nauðsynjatökuorð en innlendu orðin eru tökumerkingar lat. figura.

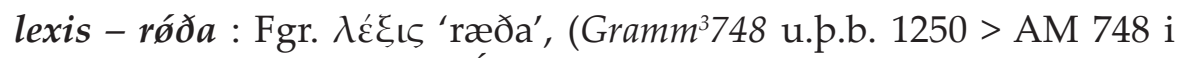
b 4to 1300-1325, Björn M. Ólsen 1884) er verknaðarnafn af so. $\lambda \varepsilon ́ \gamma \omega$ 'segja', en sambandi físl. no. rǿda (Eg1620(2001) 1220-1230 > AM 162 a $\theta$ fol. u.p.b. 1250, Bjarni Einarsson 2001) og so. róða er eins háttað. Innlenda orðið, sem er erfðaorð (sbr. got. rapjo 'tala, frásögn, skýring', fsax. rethia 'frásögn', fhp. reda 'ræða, frásögn' og líka so. got. rodjan, ffrís. rēda 'tala, ræða'), er notað sem pýðing á erlenda heitinu og ber pví að túlka petta síðara sem augnablikstökuorð. Ólafur útskýrir gríska orðasambandið $\sigma \chi \tilde{\eta} \mu \alpha \lambda \varepsilon^{\prime} \xi \varepsilon \omega \varsigma$ 'form ræðunnar' með pví að pýða pað, eins og gert var fyrir lat. solœecismus (sjá einnig neðar, u. schema-skrúd).

nótera - merkja : Físl. nótera (Gramm ${ }^{3} 748$ u.p.b. 1250 > AM 748 i b 4to 1300-1325, Björn M. Ólsen 1884) er talið vera fengið úr lat. notare 'merkja, pýða' í íslenskum orðsifjabókum (IeW, u. nótera, nótéra; AeW, u. notéra; ÍOb, u. nótera). Í IeW segir Alexander Jóhannesson að viðskeytið -era sé „eftir pýskri fyrirmynd“ (mín pýðing). Sagnorð sem enda á -era eru yfirleitt talin fengin úr miðlágpýsku vegna áhrifa frá Hansasambandinu (sjá Veturliða Óskarsson 2002 og 2003). Par af leiðandi bæri að túlka físl. nótera frekar pannig að pað sé úr mlp. notēren (<lat.).

Físl. merkja (Eyv Hál 10 ${ }^{\text {th }}$ c. > AM 45 fol. 1300-1325, LP) er formlega 
leitt af no. mark og er erfðaorð. Skyld pessu sagnorði í germönsku málafjölskyldunni eru t.d. fsax. merkian 'merkja, taka eftir', fhp. merken 'útskýra, skynja, skilja, taka eftir'. Sbr. einnig fe. mearcian 'merkja, afmarka', físl. marka.

Sambandi pessara tveggja orða hlýtur að vera pannig háttað að tökuorðið hafi ratað inn í málið pegar innlenda orðið var pegar komið í notkun. Tökuorðið ber pví að túlka sem virðingartökuorð.

nóti - merking : Físl. nóti (Gramm 3748 u.p.b. 1250 > AM 748 i b 4to 1300-1325, Björn M. Ólsen 1884) er talið vera beint tökuorð úr lat. nota 'mark, tákn' í AeW (u. nóti) og IeW (u. nóta, nóti). ÍOb (u. nóti) telur hins vegar að pað sé fengið úr mhp. nōte 's.m.' frekar en beint úr latínu. Alexander Jóhannesson, meðal annarra, nefnir mlp. nōte, en pað orð er ekki að finna í miðlágpýskri orðabók Schillers og Lübbens. Fsax. nota '(letur)tákn' er varðveitt og sömuleiðis er orðið til í miðhollensku (noot < ffr. note eða beint úr latínu, EWNed., u. noot). Miðlágpýska hefur orðið not(t)ele 'skjal', sem er eflaust fengið úr lat. notula (smækkunarorð fyrir nota). Að pessu sögðu má telja líklegt að miðlágpýska hafði orðið nōte, pó að pað sé ekki varðveitt. Miðlágpýska væri líklegasta veitimálið fyrir físl. nóti.

Aðlögun orðsins í forníslensku (an-stofn) ber sennilega vitni um að mlp. nōte liggi til grundvallar frekar en lat. nota. Ef öfugt væri, pá hefði orðið sennilega verið aðlagað íslensku sem ōn-stofn. Ísl. nóta (frá u.p.b. 1650, RitOH) er hins vegar væntanlega beint lært tökuorð úr latínu.

Físl. merking (GrgStað 12 ${ }^{\text {th }}$ c. > AM 334 fol. 1260-1270, Vilhjálmur Finsen 1879) er leitt af so. merkja (innlent nýgert orð). Mlp. merkunge, merkinge 'athygli, tillit' hafa væntanlega orðið til í pví máli og hafa öðruvísi merkingu en íslenska orðið.

Líklegast er að físl. merking hafi verið til áður en tökuorðið kom til sögunnar svo að tökuorðið er væntanlega virðingartökuorð.

paronomasia-aðalhending : Lat. paronomasia 'orðaleikur sem byggist á pví að nota saman samhljóða orð sem hafa pó ólíka, jafnvel andstæða, merkingu' (Gramm 3748 u.p.b. 1250 > AM 748 i b 4to 1300-

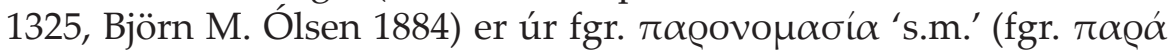

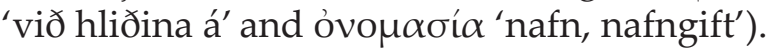

Físl. aðalhending (SnE u.p.b. $1220>$ GKS 2367 4to 1300-1350, Finnur Jónsson 1931) er samsett af fsk. aðal- og no. hending.

Ólafur ber hér saman tvö ólík fyrirbæri. Annars vegar málskrúðsfígúru sem byggist á samspili hljóðmyndar og merkingar, en hins 
vegar bragfræðilegt fyrirbæri. Раð eina sem pau eiga sameiginlegt er að byggja á samræmi hljóða (samhljóða orðum annars vegar og alrím hins vegar). Aðalhendingar varða innlenda kveðskaparhefð og er pví eðlilegt að túlka orðið sem innlent nýgert orð. Eins og drepið hefur verið á að framan um lat. anadiplosis, ber einnig að túlka lat. paronomasia sem nauðsynjatökuorð.

partr-hlutr : Físl. partr (Alex 1262-1263 > AM 519 a 4to ca. 1280, Finnur Jónsson 1925) er talið fengið úr mlp. part (< ffr. part< lat. pars) í AeW (u. parta, partera) og ÍOb (u. partur). Alexander Jóhannesson (IeW, u. partr) túlkar orðið sem fengið úr fornfrönsku. Af ritmyndunum að dæma virðast báðar tillögurnar jafnlíklegar, en fornfrönsku og miðlágpýsku myndirnar eru eins. Samt sem áður er tökuferli í AeW og ÍOb líklegra, ef tekið er tillit til tengsla Íslands og lágpýskumælandi svæðis á miðöldum (sbr. Veturliða Óskarsson 2003:292-293).

Físl. hlutr (Fjóð Yt $9^{\text {th }}$ c. > AM 35 fol. 1675-1700, LP) er erfðaorð. Samstofna pessu orði í germönsku eru t.d. fe. hlot 'hluti, partur', fsax. hlot 's.m.', fhp. lōz 's.m.'. Enginn vafi leikur á að innlenda orðið hafi fyrst verið notað í málsamfélaginu. Tökuorðið ber pví að túlka sem virðingartökuorð.

periphrasis-umkringingarmál: Lat.periphrasis 'umorðun' (Gramm ${ }^{3} 748$ u.p.b. 1250 > AM 748 i b 4to 1300-1325, Björn M. Ólsen 1884) er úr fgr.

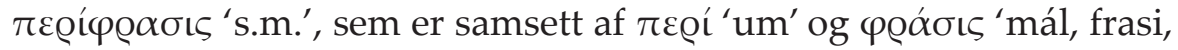
orðatiltæki'.

Físl. umkringingarmál (Gramm 348 u.p.b. $1250>$ AM 748 i b 4to 1300-1325, Björn M. Ólsen 1884) er samsett af *umkringing ‘pað аð fara í kringum', leitt af so. umkringja, og mál. Orðið er bein pýðing á lat. circumlocutio.

Grísk-latneska orðið er augnablikstökuorð sem líklega er fengið beint úr Donatusi. Forníslenska orðið virðist hins vegar samsvara texta Donatusar að pví leyti að pað er pýðing á orðinu sem Donatus notar til að útskýra periphrasis, p.e. circumlocutio, en petta síðara orð er

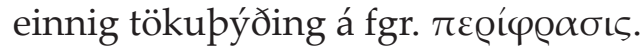

philosophus-spekingr: Lat.philosophus '(heim)spekingur' $\left(\right.$ Gramm $^{3} 748$ u.p.b. 1250 > AM 748 i b 4to 1300-1325, Björn M. Ólsen 1884) er úr fgr.

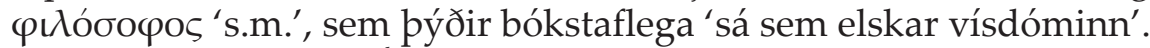

Físl. spekingr (HómÍsl(1993) u.p.b. $1200>$ Stock. perg. 15 4to u.p.b. 1200, de Leeuw van Weenen 1993) er leitt af lo. spakr. Innlenda orðið virðist hafa verið smíðað óháð grísk-latneskri fyrirmynd, en pað 
pýðir 'vísdómsmaður' en ekki '(heim)spekingur' í elstu varðveittum heimildum (sjá ONP, u.o.). Рað ber pví að túlka sem innlent nýgert orð, en tökuorðið er virðingartökuorð.

punkta - stinga : Físl. punkta (Gramm 3748 u.p.b. 1250 > AM 748 i b 4to 1300-1325, Björn M. Ólsen 1884) er leitt af punktr (StjC 1250-1260 > AM 228 fol. u.p.b. 1300-1325, Astås 2009). AeW og ÍOb telja að físl. punktr sé komið annað hvort úr fe. punct eða mlp. punkt. Вæði orðin ber að rekja til lat. punctus. IeW telur hins vegar að punktr sé beint tökuorð úr latínu. Pó að físl. punkta sé í raun og veru innlend smíð og ekki fengið að utan, ber pað, í samanburði við físl. stinga, vott um erlend áhrif í íslensku.

Físl. stinga (HómÍsl(1993) u.p.b. 1200 > Stock. perg. 15 4to u.p.b. 1200, de Leeuw van Weenen 1993) er erfðaorð og eru eftirfarandi orð úr germönsku málafjölskyldunni samstofna íslenska orðinu: got. *usstaggan 'taka úr', OE stingan 'prýsta, stinga' (sjá enn fremur IdgeW, u. stegh-, nasal. stengh- og LIV', u. stegh-).

Samband milli pessara tveggja orða er nokkuð skýrt, en físl. punkta hlýtur að hafa komist í notkun eftir að samsvarandi íslenskt samheiti var komið fram.

rhetorica - málssnilldarlist : Lat. rhetorica (ars) 'málsskrúðslist, retórík' (Gramm3748 u.p.b. 1250 > AM 748 i b 4to 1300-1325, Björn M. Ólsen 1884) er úr fgr. @̣ๆ

Físl. málssnilldarlist (AugA $13^{\text {th }}$ c. > AM 234 fol. u.p.b. 1340, Unger 1877) er samsett af mál(s)snilld (HómÍsl(1993) u.p.b. $1200>$ Stock. perg. 15 4to u.p.b. 1200, de Leeuw van Weenen 1993) og list. Orðið er tökupýðing á grísk-latneska orðinu sem er tekið inn í íslensku vegna nauðsynjar. Í PMR útskýrir erlenda orðið pað innlenda, en venjulega er skýringarinnskotum öfugt háttað. Skýringarinnskot par sem físl. málssnilldarlist útskýrir lat. rethorica er að finna í Ágústínus sögu, og er pað elsta heimild um orðið málssnilldarlist.

schema - skrúð : Fgr. $\sigma \chi \tilde{\eta} \mu \alpha$ 'form' (Gramm³748 u.p.b. 1250 > AM 748 i b 4to 1300-1325, Björn M. Ólsen 1884) er skylt so. ع̌ $\chi \omega$ 'eiga' (GeW,

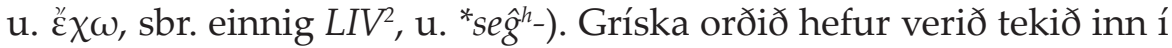
latínu sem schema 'lögun, háttur'.

Físl. skrúð (HómÍsl(1993) u.p.b. $1200>$ Stock. perg. 15 4to u.p.b. 1200, de Leeuw van Weenen 1993) er mögulega fengið úr fe. scrúd 'klæði, flík' skv. ÍOb (u. skrúð). De Vries (AeW, u. skrúð) er sömu skoðunar en bætir pví við að ef orðið væri hins vegar innlent í norðurgermönsku, 
pá væri pað skylt skrjóðr og fleiri orðum. Alexander Jóhannesson (IeW, u. sqer-, qer-) telur að físl. skrúð sé einmitt innlent. Ef hugað er að pví hversu pröngt merkingarsvið fornenska orðsins er, pá er erfitt að útskýra hvernig pað hafi víkkað svo mikið í íslensku. Ef til vill er enska orðið tökuorð úr norrænu, ef ekki erfðaorð (sbr. fe. scréadian 'rífa, skera í tætlur', scréade 'ræma, tætla' og enn fremur $V W g s V$, u. skraud-a-).

Eins og haldið hefur verið fram ofar u. lexis - rǿða, er innlenda orðið notað sem hjálparpýðing á erlenda orðinu sem er par af leiðandi augnablikstökuorð.

sen - merking : Físl. sen (Gramm³748 u.p.b. 1250 > AM 748 i b 4to 13001325, Björn M. Ólsen 1884) er talið vera tökuorð úr ffr. sen 'merking, vit, skynsemi' í ÍOb (u.o.). Alexander Jóhannesson (IeW, u. seni-, senu-, sn-ter) telur pað innlent en de Vries $(A e W$, u. sen) reiknar með að pað sé tökuorð pó að hann drepi stuttlega á pann möguleika sem IeW setur fram. Orðið er vafalaust germanskt að uppruna (sbr. mhp., mlp. sin 'merking, vit, skynsemi') og pví germanskt tökuorð í frönsku, sennilegast úr ffrk. *sin 'merking, vit, skynsemi' (sbr. fr. asséner 'stefna að, miða á' sem leitt er af sen 'átt, stefna'). Í frönsku hefur pað gerst að sen hefur vikið fyrir innlenda orðinu sens, en merkingarsvið peirra sköruðust að mörgu leyti (sjá einnig Gamillscheg 1934:274). Dreifing pessa germanska tökuorðs í rómönskum málum bendir sterklega til að orðið sé vesturgermanskt tökuorð í peim málum, og pá úr fornfrönsku (sbr. $R E W$, u. sinn). Öfugt við frönsku eru orðin tvö varðveitt í ítölsku, p.e. senso 'skilningarvit, skynjunarhæfileiki, skyn, skynjun, meðvitund' (/scnso/ < lat. sensus) og senno 'vit, skynsemi, hyggjuvit' (/sen:o/ < ffrk. *sin, væntanlega um ffr. *sen). Í germönsku málafjölskyldunni er orðið einungis að finna í íslensku auk meginlandsvesturgermönsku. Petta pýðir að orðið er líklegast fengið að láni og pví ekki erfðaorð í íslensku. Um físl. merking sjá ofar u. nóti-merking.

Ef hugað er m.a. að tímabili elstu heimilda um pessi tvö orð, má segja að tökuorðið hafi komið inn í málið pegar innlenda orðið var pegar í notkun. Físl. sen hefur sennilega verið eitt peirra orða sem Íslendingar lærðu í námi erlendis og ber pví að túlka sem virðingartökuorð (um menntun Íslendinga á miðöldum sjá Gunnar Harðarson 2016).

vers - vísuord : Físl. vers (HómÍsl(1993) u.p.b. 1200 > Stock. perg. 15 4to u.p.b. 1200, de Leeuw van Weenen 1993) er talið vera tökuorð úr mlp. vers 'vers, vísuorð' (< Lat. versus 's.m.') í AeW og ÍOb (u. vers). IeW ber íslensku saman við aðrar myndir sama tökuorðs í germönsku 
málunum og segir að allar beri að rekja til lat. versus. Hvað íslenska orðið varðar er pað sennilega úr miðlágpýsku frekar en beint úr latínu, en pó má ekki útiloka alveg seinni möguleikann.

Físl. vísuorð (SnE u.p.b. $1220>$ GKS 2367 4to 1300-1350, Finnur Jónsson 1931) er ákvörðunarsamsetning af vísa og orð. Orðið er innlent nýgert orð.

Ekki er einfalt að meta samband pessara tveggja orða. Pað má pó stinga upp á pví að orðin vísi til kjarnahugtaks í skáldskap og væri pví helst við pví að búast að innlent orð hafi verið tekið í notkun fyrst. Ef petta er rétt athugað, pá ber að túlka tökuorðið sem virðingartökuorð.

\section{Niðurstöður}

Samheitapör í íslensku sem koma fram áður en hreintungustefna nær að blómstra bera vitni um að samspil orðanna hefur alltaf verið hluti af sögu íslensks orðaforða. Tilgangurinn með að taka inn í málið tökuorð, eða smíða samheiti peirra, er fyrst og fremst sá að auka orðaforða og auðga málið. Samheitapörin í PMR eru mun fleiri en í Fyrstu, Annarri og Fjórðu málfræðiritgerðinni og flest peirra tilheyra merkingarsviðunum málfræði og málskrúðs- og skáldskaparfræði. Flest orðin teljast pví til íðorða. Samheitapörin birtast á fjóra vegu, p.e. í skýringarinnskotum og samheitatvennum, til skiptis í textanum og á sambærilegum stöðum í mismunandi handritum. Tafla 3 sýnir dreifingu birtingartegunda eftir merkingarsviðum:

\begin{tabular}{|l|c|c|c|c|}
\hline & $\begin{array}{l}\text { Skýr- } \\
\text { ingar- } \\
\text { innskot }\end{array}$ & $\begin{array}{l}\text { Sam- } \\
\text { heita- } \\
\text { tvenna }\end{array}$ & $\begin{array}{l}\text { Birting til } \\
\text { skiptis í } \\
\text { textanum }\end{array}$ & $\begin{array}{l}\text { Birting á } \\
\text { sambæri- } \\
\text { legum } \\
\text { stöðum }\end{array}$ \\
\hline Almennur lærdómur & 1 & & & \\
\hline Eiginleikar & & & 1 & \\
\hline Magn & 1 & 1 & & \\
\hline Málfræði & 10 & & 1 & \\
\hline $\begin{array}{l}\text { Málskrúðs- og } \\
\text { skáldskaparfræði }\end{array}$ & 1 & 1 & & \\
\hline Náttúra & & & 2 & 1 \\
\hline Sagnir
\end{tabular}

Tafla 3: Samanburður milli merkingarsviða samheitapara og birtingartegundir peirra. 
Af pessum samanburði sést að samheitin birtast í skýringarinnskotum í langflestum tilvikum pegar um íðorðaforða er að ræða. Má pá draga pá ályktun að birting samheitapara í PMR sé tengd tilgangi höfundar með ritgerðinni, eða m.ö.o. að petta fyrirbæri beri að setja í bein tengsl við eðli PMR sem málfræðiritgerðar. Hún fylgir fyrirmyndum sínum svo náið að vel má segja að hún sé tilraun til að heimfæra kenningar latnesku málfræðinganna Priscianusar og Donatusar upp á íslensku. Í orðaforðanum felst pessi tilraun fyrst og fremst í að sýna fram á pað að íslenska hafi einnig að geyma íðorð sem samsvara grísk-latnesku hugtökunum. Petta gerir höfundurinn einkum með pví að nota orð sem pá pegar voru til í málinu og einkum í sambandi við málskrúðsog skáldskaparfræðileg fyrirbæri. Útkoma pessarar vinnuaðferðar er pó langt frá pví að vera fullkomin, en Ólafur notar íslensk heiti yfir hugtök sem hafa lítið sameiginlegt með peim fyrirbærum sem hann er að lýsa, eins og pegar hann pýðir orðið aðalhending með lat. paronomasia. Pessi vinnuaðferð skín víða í gegn í PMR og má geta pess að Ólafur er sannfærður um að íslenska hafi prenns konar hljóðsgreinar, p.e. áherslutegundir (hvassa, punga og umbeygilega hljóðsgrein < lat. acutus, gravis, circumflexus tenor/accentus < fgr. ỏ $\xi \varepsilon \tau \alpha$,

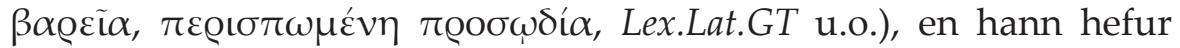
pessa greiningu eftir Priscianusi, og er hún jafn óviðeigandi í latínu eins og hún er í íslensku par sem hún átti heima í forngrísku. ${ }^{7}$

Að lokum skal vikið nokkrum orðum að sambandinu á milli tegunda tökuorða (nauðsynja- og virðingartökuorða) og innlendra orða (tökupýðinga, innlendra nýgerðra orða, tökumerkinga, erfðaorða) með tilliti til PMR. Augnablikstökuorðin eru ekki tekin með par sem pau koma einvörðungu fyrir sem skýringarinnskot.

\begin{tabular}{|l|l|l|}
\hline Samheitapar & Tegund tökuorðs & Tegund innlends orðs \\
\hline anadiplosis - drogur & nauðsyn & innlent nýgert orð \\
\hline apocope-orðkolfr & nauðsyn & innlent nýgert orð \\
\hline $\begin{array}{l}\text { (cœlestis) armonia - } \\
\text { (himnesk) hljóðagrein }\end{array}$ & virðing & $\begin{array}{l}\text { tökupýðing } \\
\text { (með annarri fyrirmynd en } \\
\text { tökuorðinu) }\end{array}$ \\
\hline diphthongus - tvíhljóðr & nauðsyn & tökupýðing \\
\hline
\end{tabular}

Раð að Ólafur fer nákvæmlega eftir latneskri fyrirmynd sést m.a. í dæmi sem hann tilfærir pegar hann talar um hljóðsgreinarnar prjár, en hann útskýrir petta m.a. með аð nota beygingarmyndirnar ari, aranna, ara (Björn M. Ólsen 1884:42) par sem Priscianus notar aræ, ararum, ara, p.e. nf./pf. flt., ef. flt. og svf. et. af ara 'fórnarstaður'. Рað liggur í augum uppi að beygingarmyndirnar sem Ólafur notar eru einmitt valdar vegna hljóðlíkingar peirra við myndirnar sem Priscianus notar. 


\begin{tabular}{|l|l|l|}
\hline Samheitapar & Tegund tökuorðs & Tegund innlends orðs \\
\hline enigma-gáta & nauðsynjatökuorð & erfðaorð \\
\hline f'́gúra-mynd/voxtr & nauðsynjatökuorð & tökumerking \\
\hline nótera-merkja & virðingartökuorð & erfðaorð \\
\hline nóti-merking & virðingartökuorð & innlent nýgert orð \\
\hline $\begin{array}{l}\text { paronomasia } \\
\text { aðalhending }\end{array}$ & nauðsynjatökuorð & innlent nýgert orð \\
\hline partr - hlutr & virðingartökuorð & erfðaorð \\
\hline philosophus - spekingr & virðingartökuorð & innlent nýgert orð \\
\hline punkta-stinga & á ekki við & erfðaorð \\
\hline $\begin{array}{l}\text { rhetorica- } \\
\text { málssnilldarlist }\end{array}$ & nauðsynjatökuorð & tökupýðing \\
\hline sen-merking & virðingartökuorð & innlent nýgert orð \\
\hline vers - vísuorð & virðingartökuorð & innlent nýgert orð \\
\hline
\end{tabular}

Tafla 4: Gerð tökuorða og innlendra orða.

Í Töflu 4 má sjá að allar fjórar tegundir innlendra orða samsvara nauðsynjatökuorðum en á hinn bóginn svara einungis erfðaorð og innlend nýgerð orð til virðingartökuorða, pó með einni undantekningu ((cclestis) armonia - (himnesk) hljóðagrein). Tökuorð eru flokkuð sem nauðsynjatökuorð ef pau komast inn í málið pegar ekki er til innlent orð með sömu merkingu, sem getur svo verið smíðað seinna. Orð teljast til virðingartökuorða hins vegar ef pau ganga inn í orðaforðann eftir að innlent orð hefur skotið rótum í málinu. Skilyrði fyrir tökupýðingu er að erlenda orðið sé a.m.k. pekkt, ef ekki notað. Og til pess að merking erlends orðs sé færð yfir á innlent orð parf erlenda orðið einnig að vera pekkt, ef ekki notað. Par af leiðandi má segja pað sjaldgæft að pessar tvær tegundir, tökupýðingar og tökumerkingar, geti samsvarað virðingartökuorðum sem eru skv. skilgreiningu tekin inn í málið pegar til er innlent orð með sömu merkingu. Erfðaorð ættu hins vegar aldrei að samsvara nauðsynjatökuorðum. Ef pessi tvö síðastnefndu tilvik eiga sér stað má gera grein fyrir pví sem hér segir:

- Ef erfðaorð samsvarar nauðsynjatökuorði er tökuorðið annað hvort undirheiti yfir erfðaorðið eða pað er fengið sem íðorð, og hefur merkingar- og notkunarsvið pess síðan víkkað, eða innlenda orðið hefur fengið merkinguna sem íðorðið hefur (hér t.d. gáta gagnvart enigma).

- Ef tökupýðing eða -merking samsvarar virðingartökuorði kemur tvennt til greina: 1) innlenda smíðin hefur víða merk- 
ingu sem gerir pað аð verkum að pað fær einnig merkingu tökuorðsins en hún liggur nær merkingarsviði innlenda orðsins; 2) innlenda orðið hefur aðra fyrirmynd að baki en tökuorðið.

\section{Lokaorð}

Í pessari grein var rætt um samheitapör í PMR. Rannsókn á peim er páttur í stærra verkefni sem varpar ljósi á sambýli og samkeppni innlendra orða og tökuorða í forníslensku. Í niðurstöðum pessarar greinar kemur skýrt fram að í PMR nýtir höfundur sér orðasmíð og innlenda orðaforðann einkum til að innleiða vissan íðorðaforða í norrænu, enda tilheyra flest orðapör merkingarsviðum málfræði og málskrúðs- og skáldskaparfræði. Petta gerir Ólafur hvítaskáld, höfundur PMR, fyrst og fremst með pví að nota skýringarinnskot og er pessi aðferð ekki mjög frábrugðin peirri sem notuð er nú á dögum, par sem erlent, alpjóðlegt orð er oft látið fylgja innlendri orðasmíð, og pá innan gæsalappa eða sviga. Í orðapörum sem tilheyra hins vegar venjulegri orðaforða, ef svo má að orði komast, er engin birtingartegund í meirihluta, en petta er í samræmi við minni sérstöðu ásamt meiri útbreiðslu og notkun pess hluta orðaforðans.

\section{Heimildir}

AeW $=$ de Vries, Jan. 2000. Altnordisches etymologisches Wörterbuch. 4. útg. Leiden: Brill.

Ari Páll Kristinsson. 2004. Offisiell normering av importord i islandsk. Í: Sandøy, Helge og Jan-Ola Östman (ritstj.), "Det främmande" i nordisk språkpolitikk, bls. 30-70. Oslo: Novus.

Ari Páll Kristinsson og Amanda Hilmarsson-Dunn. 2015. Implications of language contact: Evaluating the appropriateness of borrowings in written Icelandic. Í: Hilpert, Martin o.fl. (ritstj.), New Trends in Nordic and General Linguistics, bls. 55-67. Linguae \& litterae 42. Berlin: de Gruyter.

Ásta Svavarsdóttir. 2003. Tilpasning af importord i islandsk. Í: Sandøy, Helge (ritstj.), Med 'bil' i Norden i 100 år, bls. 75-81. Oslo: Novus.

Ásta Svavarsdóttir og Veturliði Óskarsson. 2009. Annarleg sprek á ókunnugri strönd: Tökuorð í íslensku fyrr og nú. Orð og tunga 11:17-44.

Betz, Werner. 1959. Lehnwörter und Lehnprägungen im Vor- und Frühdeutschen. Í: Maurer, Friedrich og Friedrich Stroh (ritstj.), Deutsche Wortgeschichte I, bls. 127-147. Berlin / New York: de Gruyter. 
Björn M. Ólsen (ritstj.). 1884. Den tredje og fjærde grammatiske afhandling $i$ Snorres Edda. STUANGL XII. Kaupmannahöfn: Fr.G. Knudtzon.

Borgnet, C.A. (ritstj.). 1895. Alberti Magni Opera Omnia /34, Compendium theologicæ veritatis in septem libros digestum. París.

Durkin, Philip. 2009. The Oxford Guide to Etymology. Oxford: Oxford University Press.

Eiríkur Jónsson and Finnur Jónsson (ritstj.). 1892-1896. Hauksbók: udgiven efter de Arnamagnæanske håndskrifter no. 371, 544 og 675, 4 'samt forskellige papirshåndskrifter af Det Kongelige Nordiske Oldskrift-Selskab. Kaupmannahöfn: Thieles Bogtrykkeri.

Eriksen, Stefka (ritstj.), Intellectual Culture in Medieval Scandinavia, c. 11001350, bls. 35-73. Turnhout: Brepols.

EWNed. = Philippa, Marlies et al. (eds.). 2004-2009. Etymologisch woordenboek van het Nederlands. Amsterdam: Amsterdam University Press.

Finnur Jónsson (ritstj.). 1925. Alexanders saga. Kaupmannahöfn: Gyldendal.

Finnur Jónsson (ritstj.). 1927. Óláfr Pórðarson málhljóða- og málskrúđsrit. Det Kgl. Danske Videnskabernes Selskab Historisk-filologiske Meddelelser XIII, 2. Kaupmannahöfn: Bianco Luno.

Finnur Jónsson (ritstj.). 1931. Edda Snorra Sturlusonar. Kaupmannahöfn: Gyldendal.

Frans, Victor. 2019. Sub regulis Donati. Pseudo-Remigius Ars Brugensis och Den tredje grammatiska avhandlingen. MA-ritgerð við Oslóarháskóla.

Gamillscheg, Ernst. 1934. Romania Germanica I. Berlín/Leipzig: de Gruyter.

GeW = Frisk, Hjalmar. 1973. Griechisches etymologisches Wörterbuch. Heidelberg: Winter.

Guðrún Kvaran. 2003. Typer af nye ord i islandsk. Í: Sandøy, Helge (ritstj.), Med 'bil' i Norden i 100 år, bls. 33-41. Oslo: Novus.

Guðrún Kvaran. 2005. Orð. Íslensk tunga II. Reykjavík: Almenna bókafélagið.

Gunnar Harðarson. 2016. Old Norse Intellectual Culture: Appropriation and Innovation. Í: Stefka G. Eriksen (ritstj.), Intellectual Culture in Medieval Scandinavia, c. 1100-1350, bls. 35-73. Turnhout: Brepols.

Gusmani, Roberto. 1981. Saggi sull'interferenza linguistica I. Firenze: Le Lettere.

Halldór Halldórsson. 1964. Nýgervingar í fornmáli. Í: Halldór Halldórsson (ritstj.), Pættir um íslenzkt mál, bls. 110-133. Reykjavík: Almenna bókafélagið.

Hreinn Benediktsson (ritstj.). 1972. The First Grammatical Treatise. University of Iceland Publications in Linguistics 1. Reykjavík: Institute of Nordic Linguistics.

IdgeW = Pokorny, Julius. 1959-1969. Indogermanisches etymologisches Wörterbuch. Bern: Francke.

IeW = Alexander Jóhannesson. 1956. Isländisches etymologisches Wörterbuch.

Bern: Francke. 
ÍOb= Ásgeir Blöndal Magnússon. 1989. Íslensk orðsifjabók. Reykjavík: Orðabók Háskólans.

Jarvad, Pia. 2007. Tilpasning af engelske ord i bøjning og udtale i de nordiske sprog. Í: Jarvad, Pia og Helge Sandøy (ritstj.), Stuntman og andre importord i norden, bls. 9-26. Oslo: Novus.

Jón Axel Harðarson. 2016. Donat und Priscian in Island. Í: Molinari, Alessandra og Michael Dallapiazza (ritstj.), Mittelalterphilologien heute I, bls. 63-77. Würzburg: Königshausen \& Neumann.

Kjartan G. Ottósson. 1990. Íslensk málhreinsun. Sögulegt yfirlit. Rit Íslenskrar málnefndar 6. Reykjavík: Íslensk málnefnd.

de Leeuw van Weenen, Andrea (ritstj.). 1993. The Icelandic Homily Book: perg. 15 to in the Royal Library. Stockholm. Reykjavík: Stofnun Árna Magnússonar á Íslandi.

LeW = Walde, Alois. 1956-1972. Lateinisches etymologisches Wörterbuch. Edited by J.B. Hoffmann. Heidelberg: Winter.

Lex. Lat.GT = Schad, Samantha. 2007. A Lexicon of Latin Grammatical Terminology. Studia Erudita 6. Pisa/Roma: Fabrizio Serra Editore.

$L I V^{2}=$ Rix, Helmut et al. (ritstj.). 2001. Lexikon der indogermanischen Verben. 2. útg. Wiesbaden: Reichert Verlag.

LP $=$ Sveinbjörn Egilsson. 1931. Lexicon Poeticum antiqvæ lingvæ septentrionalis. 2. útg. Finnur Jónsson gaf út. Kaupmannahöfn: S. L. Møller.

Magnús Snædal. 1993. Yfirlit yfir forníslenskar málfræðiritgerðir. Íslenskt mál og almenn málvísindi 15:207-220.

Males, Mikael. 2018. Pseudo-Remigius and the Old Icelandic Barbarismus: A Pilot Study. Í: Edzard, Lutz, Jens Wilhelm Borgland og Ute Hüsken (ritstj.), Reading Slowly. A Festschrift for Jens E. Baarvig, bls. 321-331. Wiesbaden: Harrassowitz Verlag.

$\mathrm{ONP}=$ Ordbog over det norrøne prosasprog. http://onp.ku.dk. Kaupmannahöfn: Københavns Universitet.

Raschellà, Fabrizio D. 2004. Tradizione locale e modelli stranieri nella terminologia grammaticale islandese medievale. Í: Dolcetti Corazza, Vittoria og Renato Gendre (ritstj.), I Germani e gli altri II parte, bls. 3-37. Alessandria: Edizioni dell'Orso.

RitOH = Ritmálssafn Orđabókar Háskólans. Stofnun Árna Magnússonar í íslenskum fræðum. http://ritmalssafn.arnastofnun.is (mars 2020).

Scherabon Firchow, Evelyn og Karen Grimstad (ritsti.). 1989. Elucidarius in Old Norse translation. Reykjavík: Stofnun Árna Magnússonar á Íslandi.

Schiller, Karl and August Lübben. 1875-1881. Mittelniederdeutsches Wörterbuch. Bremen: Kühtmann.

Tarsi, Matteo. Væntanl. Loanwords and native words in Old and Middle Icelandic (12th c.-1550). Doktorsritgerð.

Tinna Frímann Jökulsdóttir o.fl. 2019. Um nýyrði sem tengjast tölvum og tækni. Orð og tunga 21:101-128.

Unger, Carl Rikard (ritstj.). 1877. Heilagra manna søgur. Christiania: Bentzen. 
Veturliði Óskarsson. 2002. Niederdeutsche Lehnwörter im Isländischen. Greifswalder Universitätsreden 104:7-27.

Veturliði Óskarsson. 2003. Middelnedertyske låneord $i$ islandsk diplomsprog frem til år 1500. Bibliotheca Arnamagnæana XLIII. Kaupmannahöfn: C.A. Reitzel.

Veturliði Óskarsson. 2015. Loanwords with the prefix be-in Modern Icelandic: An example of halted borrowing. Orð og tunga 17:1-26.

Vilhjálmur Finsen (ritstj.). 1879. Grágás efter det Arnamagnæanske Haandskrift nr. 334 fol., Staðarhólsbók. Kaupmannahöfn: Gyldendal.

$V W g s V=$ Seebold, Elmar. 1970. Vergleichendes und etymologisches Wörterbuch der germanischen starken Verben. The Hague / Paris: Mouton.

Wills, Tarrin. 2001. The Foundation of Grammar: An edition of the first section of Óláfr Dórðarson's grammatical treatise. Doktorsritgerð. Sidney.

\section{Skammstafanir úr Ordbog over det norrøne prosasprog og Lexicon Poeticum}

Alex: Alexanders saga

Algor: Algorismus

AugA: Ágústínus saga, AM 234 fol.

Eg1620(2001): Egils saga, AM 162 a $\theta$ fol.

Eluc674(1989): Elucidarius, AM 674 4to

Eyv: Eyvindr skáldaspillir Finnsson

Gestumbl: Gestumblindi

Gramm ${ }^{3} 748$ : Priðja málfræðiritgerðin, AM 748 i b 4to

Hál: Háleygjatal (Eyv)

Heiðr: Heiðreks gátur (Gestumbl)

HómÍsl(1993): Íslensk hómilíubók

HSt: Hallar-Steinn

Rst: Rekstefja (HSt)

SnE: Snorra-Edda, GKS 2367 4to

Yt: Ynglingatal (Pjóð)

Pjóð: Pjóðólfr ór Hvini

GrgStað: Grágás, AM 334 fol.

\section{Lykilorð}

forsaga hreintungustefnunnar, forníslenska, málfræðiorðaforði, nýyrði, orðmyndun, tökuorð

\section{Keywords}

prehistory of language purism, Old Icelandic, linguistic terminology, neologisms, word formation, loanwords 


\begin{abstract}
The article is concerned with the coexistence and interplay of loanwords and native words (synonymic word pairs) in the Third Grammatical Treatise. The discussion offered in the present article is part of a larger research project on loanwords and native synonyms in Icelandic in the period from the twelfth century to around 1550. The focus of this article is on how loanword/native word pairs appear in the Third Grammatical Treatise and thus on the dynamics at the core of the alternation between loanwords and native words in this work. In addition, the research seeks to establish a relative chonology for the constituents of each word pair. Finally, the dynamics between loanwords and native words in the lexicon are illustrated in a set of generalizations.
\end{abstract}

Matteo Tarsi

Íslensku- og menningardeild

Háskóli Íslands

mat17@hi.is

orcid.org/0000-0001-6548-7874 


\section{Errata corrige}

Samspil tökuorða og innlendra orða í priðju málfræðiritgerðinni

> : leiðrétta sem

bls. 73: hvaða merkingarfræðilega sviði > hvaða merkingarfræðilegu sviði

bls. 76: og heimildum Ólafs, Donatus og Pseudo-Remigius [...] > og heimildum Ólafs, Priscianus, Donatus og Pseudo-Remigius [...]

bls. 90, nmgr. 7: ari, aranna, ara > ári, áranna, ára; arae ... nf./pf. flt. > nf./ávf. flt.

Heimildir

Eyða eftirfarandi færslum:

के Borgnet, C.A. (ritstj.). 1895

¿ Eriksen, Stefka (ritstj.) 